\title{
Angular Distributions of Scattered Ne and Ar Ions at the Grazing Incidence on the InGaP (001) <110> Surface
}

\author{
M.K. Karimov*, U.O. Kutliev, K.U. Otabaeva, M.U. Otabaev \\ Urgench State University, 14, Khamid Olimjan St., Urgench 220100, Uzbekistan
}

(Received 23 March 2020; revised manuscript received 15 October 2020; published online 25 October 2020)

\begin{abstract}
In this paper, we report on measurements of angular distributions in grazing scattering of $\mathrm{Ne}$ and $\mathrm{Ar}$ ions incident along the $<110>$ direction of the InGaP (001) surface. In our calculation, we used method of binary collision approximation. The specificity of the theoretical consideration of multiple scattering of ions by atoms on the surface of a solid, associated with the difficulty of describing the interaction of many particles, has led to the widespread use of methods for modeling the scattering process on the computer. Our calculations showed that changes in the fall of bombarding particles lead to a change in the angular distribution. The obtained results show that by the azimuthal scattering angle $\varphi$ on the coordinate of the aiming point we observe some groups of scattered ions: from the surface atomic chain; between the bottom and the surface atomic chain; from the semichannel; from the bottom of the semichannel and the neighboring surface atomic chain; from the neighboring surface atomic chain. Also, it has been shown the dependence of characteristic trajectories on the type and initial energy of incident ions, geometric parameters of the surface. This result is very interesting for the study of surface of semiconductor material.
\end{abstract}

Keywords: Ion-solid interactions, Scattering, Computer simulations.

DOI: 10.21272/jnep.12(5).05032

PACS numbers: 34.50. $-\mathrm{s}$, 68.49.Sf

\section{INTRODUCTION}

A large number of physical processes occurring in modern devices are associated with the surface of semiconductor materials, its characteristics and response to external influences. The widespread use of thin-film technologies, heterostructures, and nanotechnology has led to the need for research. In the case of multicomponent materials, the concentration of elements on the surface can differ significantly from the bulk. Thus, the change in the composition and structure of the monoatomic layer of the surface makes it possible to form the electronic properties of a semiconductor material using metals and dielectrics as modifying materials. This allows to create heterostructures, the properties of which, in principle, cannot be obtained using the properties of the bulk of semiconductors. Therefore, obtaining complete information as possible about the composition, structure, condition of the surface and the physical processes occurring on it is an important scientific task [1-4].

In the low-energy range, probing the surface with ions allows one to obtain information on the composition, structure, and mutual arrangement of atoms of one external atomic layer, which is not available to other methods of analysis. At such initial energies of ions, difficulties arise in the hardware implementation of analytical devices associated with the difficulties in the formation of ion beams and registration of low-intensity scattered fluxes, and in the decoding of the obtained spectra, associated with the need to take into account a number of physical factors, the influence of which at higher energies could be neglected. Thus, the physical mechanism of interaction of ions with a surface in the low-energy range, taking into account the features of semiconductor materials, remains unclear [5-9].

The aim of this work is to study the angular distri- butions of scattered ions from the surface layers of a three-component heterostructure (InGaP) using smallangle ion scattering spectroscopy.

\section{METHOD OF SIMULATION AND RESULTS}

The specificity of the theoretical consideration of multiple scattering of ions by atoms on the surface of a solid, associated with the difficulty of describing the interaction of many particles, has led to the widespread use of methods for modeling the scattering process on the computer [10-12]. The construction of the trajectories of ions scattered by atoms on the surface of solid body in our algorithm is based on two assumptions: 1) only pair collisions of ions with target atoms are considered; 2) the path traversed by the ion between collisions is represented in the form of segments of straight lines [13]. To describe the interaction of particles, the universal Ziegler-Biersack-Littmark potential was used [14]. Inelastic energy loss was calculated by the Firsov formula improved by Kishinev and included in the kinematics of scattering [13]. Fig. 1 shows the grazing scattering geometry and a schematic representation of a semichannel on the InGaP (001) surface along the $<110>$ direction with an aiming platform located on it. Aiming points on the crystal surface filled a rectangle, the sides of which were divided into 100 segments in the plane of incidence of the beam (coordinate $I$ ) and 1000 segments in the perpendicular direction (coordinate $J)$. The dimensions of the aiming area were $7.59 \AA$ (half-width of the semichannel) along the $J$-coordinate and $1.43 \AA$ (interatomic distance along the $<110>$ direction) along the $I$-coordinate. It should be noted that the walls of the semichannel consist of In and Ga atoms, and the bottom of $\mathrm{P}$ atoms. The angles of incidence $\psi$ and emission $\delta$ of ions were measured from the surface, and the azimuthal scattering angle $\varphi$ was measured

\footnotetext{
*karimov_m_k@mail.ru
} 
from the selected crystal direction. The calculations were carried out for impact points uniformly covering (coordinates $I$ and $J$ ) the entire region of the target surface, where the total number of incident ions was $5 \cdot 10^{4}$.

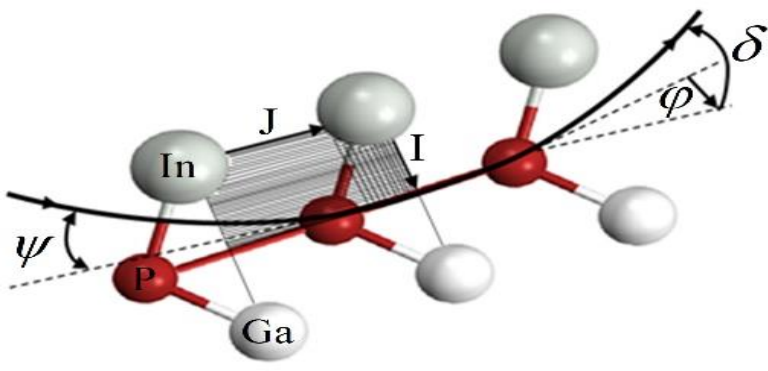

Fig. 1 - Geometry of glancing scattering and schematic representation of a semichannel formed on the $\operatorname{InGaP}(001)<110>$ surface

To consider the simultaneous and almost simultaneous collisions of ions with atoms of adjacent chains, the procedure proposed in [15] was used. Taking into account thermal vibrations, it was assumed that the target atoms vibrate independently of each other and their deviations from the equilibrium position obey the Gaussian distribution. The effect of correlation is equivalent to a decrease in the amplitude of oscillations by $\sim 5-10 \%$ depending on the effect under consideration [13].

The initial energy of incident ions varied from 0.5 to $10 \mathrm{keV}$, the grazing angles of incidence $\psi$, measured from the target surface, were $3-30^{\circ}$, and the azimuthal angles of incidence $\varphi$, realized by the rotation of the target relative to the normal to the surface and counted from the $<110>$ direction, were $0-180^{\circ}$. The polar scattering angle $\theta$ was measured from the direction of the primary beam, and the polar emission angle $\delta$ was measured from the target surface.

The paper presents a technique for analyzing and separating different types of trajectories of ions scattered by an atomic chain, two adjacent chains in the upper layer, and a semichannel on the surface of a multicomponent single crystal with a comparison of these trajectories of the corresponding sections on the targeting area of bombarding particles.

Using this technique, we carried out a detailed analysis of the effect of half-channeling on ion scattering by surface semichannels of three-component heterostructures depending on the shape of the semichannels and the incident beam parameter.

We simulated the scattering of $\mathrm{Ne}^{+}$and $\mathrm{Ar}^{+}$ions with an initial energy $E_{0}=1 \mathrm{keV}$ during the bombardment of the InGaP (001) surface along the $<110>$ direction. Angles of incidence were $\psi=3^{\circ}$ and $7^{\circ}$.

Fig. 2a shows the dependences of the azimuthal scattering angle $\varphi$ on the coordinate of the aiming point measured from the crest of the surface atomic row in the transverse direction, for $\mathrm{Ne}^{+}$ions with $E_{0}=1 \mathrm{keV}$ during the bombardment of the $\operatorname{InGaP}(001)<110>$ surface at $\psi=3^{\circ}$ and $7^{\circ}$.

And Fig. $2 \mathrm{~b}$ presents the dependences $\varphi(J)$ for $\mathrm{Ar}^{+}$ ions with $E_{0}==1 \mathrm{keV}$ shown for the bombardment of the $\operatorname{InGaP}(001)<110>$ surface at $\psi=3^{\circ}$ and $7^{\circ}$.

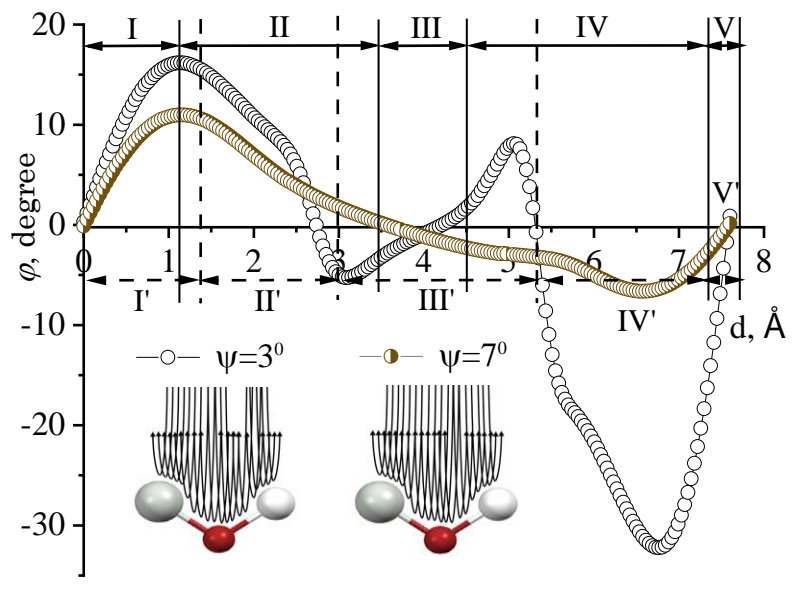

a

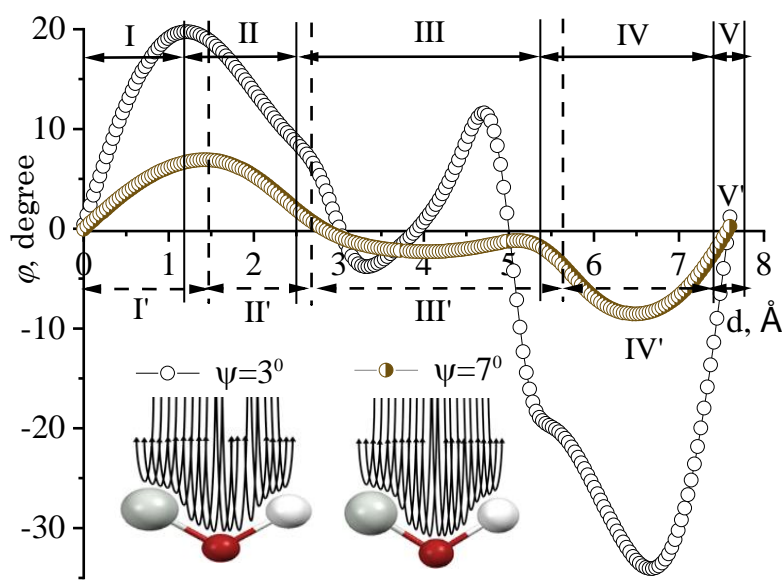

$\mathrm{b}$

Fig. 2 - Dependences $\varphi(J)$ for (a) $\mathrm{Ne}^{+}$and (b) $\mathrm{Ar}^{+}$ions with $E_{0}=1 \mathrm{keV}$ upon bombardment of the InGaP $(001)<110>$ surface at angles of incidence $\psi=3^{\circ}$ and $7^{\circ}$

According to this dependence, the scattered ions can be divided into groups, which can be described by the scattering of ions from the surface atomic chain (I), between the bottom and the atomic chain (II), from the semichannel (III), between the bottom of the semichannel and the neighboring atomic chain (IV), and from the neighbor atomic chain (V). Note that when ions are scattered from atomic chains (I and V), scattering occurs at large azimuthal angles. Comparison of the $\varphi(J)$ dependences for $\mathrm{Ne}^{+}$and $\mathrm{Ar}^{+}$ions shows that the range of group III for $\mathrm{Ar}^{+}$ions is smaller than for $\mathrm{Ne}^{+}$ions. This indicates a weakening focusing effect of the semichannel. Moreover, all these groups are illustrated in Fig. 2.

We also calculated the angular distributions of $\mathrm{Ne}^{+}$ (Fig. 3a) and $\mathrm{Ar}^{+}$(Fig. 3b) ions scattered with $E_{0}=1 \mathrm{keV}$ upon bombardment of the InGaP $(001)<110>$ surface at angles of incidence $\psi=3^{\circ}$ and $7^{\circ}$.

It can be seen from the dependences that for $\mathrm{Ne}^{+}$and $\mathrm{Ar}^{+}$ions at grazing angle $\psi=3^{\circ}$, a part of the incident ions is scattered at large azimuthal angles, while having both negative and positive values $\left(-35^{\circ}<\varphi<25^{\circ}\right)$. It should be noted that large values of the azimuthal scat- 


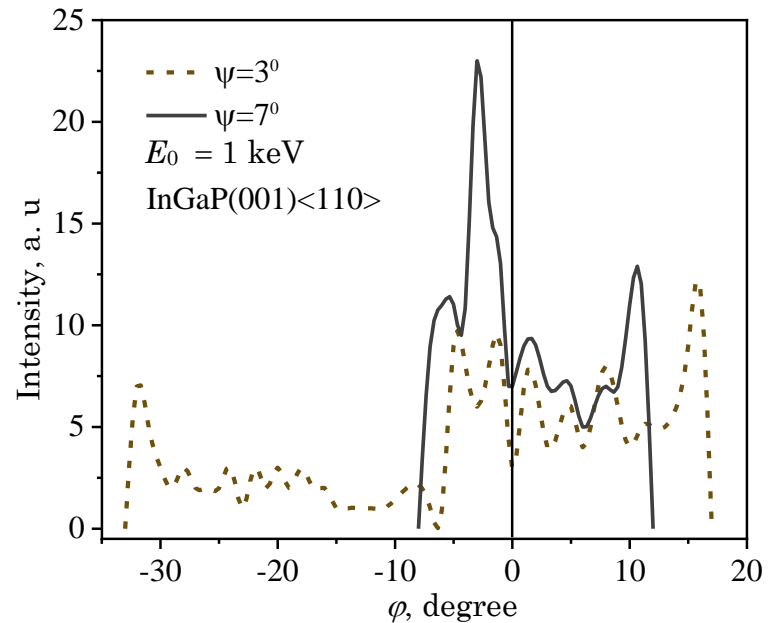

a

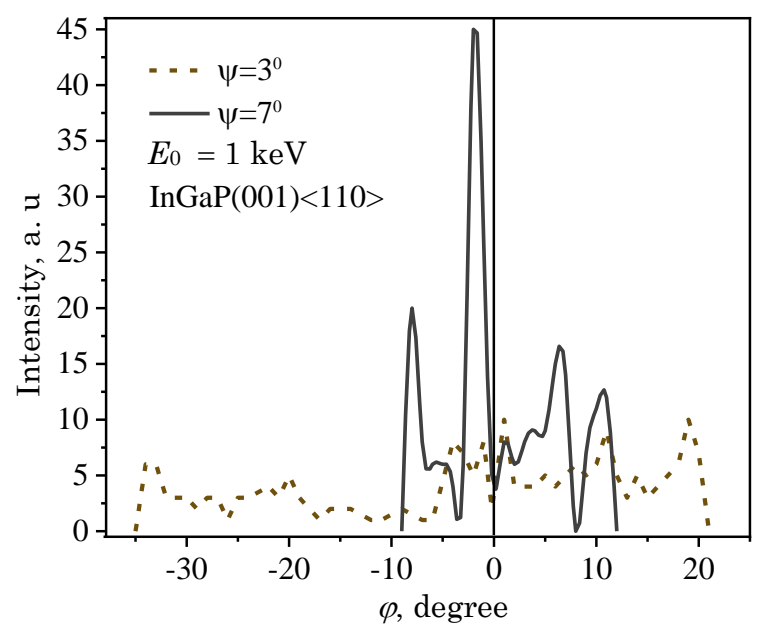

$\mathrm{b}$

Fig. 3 - Azimuthal angular distributions of $\mathrm{Ne}^{+}$(a) and $\mathrm{Ar}^{+}(\mathrm{b})$ ions scattered with $E_{0}=1 \mathrm{keV}$ during bombardment of the InGaP $(001)<110>$ surface at glancing angles $\psi=3^{\circ}$ and $7^{\circ}$

\section{REFERENCES}

1. M. Zorn, P. Kurpas, A.I. Shkrebtii, B. Junno, A. Bhattacharya, K. Knorr, M. Weyers, L. Samuelson, J.T. Zettler, W. Richter, Phys. Rev. B 60, 8185 (1999).

2. S.F. Cheng, Y. Sun, D.C. Law, S.B. Visbeck, R.F. Hicks, Surf. Sci. 600, 2924 (2006).

3. P. Brüner, T. Grehl, H.H. Brongersma, Characterization of Nanoparticles, 419 (Elsevier: 2020).

4. C.V. Cushman, P. Brüner, J. Zakel, C. Dahlquist, B. Sturgell, T. Grehl, B.M. Lunt, J. Banerjee, N.J. Smith, M.R. Linford, Appl. Surf Sci. 455, 18 (2018).

5. H.H. Brongersma, Characterization of Materials, 2024 (John Wiley \& Sons: 2012).

6. Y. Irokawa, T.T. Suzuki, K. Yuge, A. Ohi, T. Nabatame, K. Kimoto, T. Ohnishi, K. Mitsuishi, Y. Koide, Jap. J. Appl. Phys. 56, 128004 (2017).

7. D.S. Meluzova, P.Yu. Babenko, A.P. Shergin, A.N. Zinoviev, Tech. Phys. Lett. 46, 235 (2020). tering angle are associated with the scattering of ions by the In and $\mathrm{Ga}$ atomic chains, and a large azimuthal scattering angle is observed in the case of $\operatorname{In}\left(\varphi=-35^{\circ}\right)$.

With increasing values of the angle of incidence $\left(\psi=7^{\circ}\right)$ we cannot observe the scattering of ions on large azimuthal angles, since with an increase in the angle of incidence, the influence of the surface semichannel increases. Therefore, intensive peaks formed nearby $\varphi=7^{\circ}$ corresponded to rainbow scattered ions. Note that with an increase in the masses of the bombarding particles, the intensity of the scattered ions in the azimuthal angle increases.

\section{CONCLUSIONS}

We have investigated the small-angle scattering of $\mathrm{Ne}^{+}$and $\mathrm{Ar}^{+}$ions from the InGaP $(001)<110>$ surface using the semichannel model. The dependences of the azimuthal scattering angle on the coordinate of the aiming point were measured from the crest of the surface atomic row in the transverse direction for $\mathrm{Ne}^{+}$and $\mathrm{Ar}^{+}$ions with $E_{0}=1 \mathrm{keV}$ during the bombardment of the InGaP $(001)<110>$ surface at angles of incidence $\psi=3^{\circ}$ and $7^{\circ}$. Our calculations showed that changes in the fall of bombarding particles lead to a change in the angular distribution. This means that the study of the phenomenon of ion scattering by the surface is reduced to the study of the characteristic trajectories of scattered ions, which is the angular distribution of scattered ions. These characteristics are investigated depending on geometric factors (angles of incidence and scattering, crystallographic directions and type of crystal lattice), on the type of colliding particles (their mass) and the initial energy $E_{0}$.

\section{ACKNOWLEDGEMENTS}

The work was carried out within the framework of the state grant for fundamental research OT-F2-65 of the Ministry of Innovation Development of the Republic of Uzbekistan.

8. K. Umezawa, e-J. Surf. Sci. Nanotechnol. 8, 194 (2010).

9. U. Kutliev, M. Karimov, B. Sadullaeva, M. Otaboev, Compusoft. 7, 2749 (2018)

10. U.O. Kutliev, M.K. Karimov, M.U. Otaboev, Inorg. Mater.: Appl. Res. 11, 503 (2020).

11. M.K. Karimov, Kh.J. Matchonov, K. U. Otaboeva, M.U. Otaboev, e-J. Surf. Sci. Nanotechnol. 17, 179 (2019).

12. M.K. Karimov, U.O. Kutliev, Sh.K. Ismailov, M.U. Otaboev, e-J. Surf. Sci. Nanotechnol. 18, 164 (2020).

13. E.S. Parilis, L.M. Kishinevsky, N.Yu. Turaev, B.E. Baklitzky, F.F. Umarov, V.Kh. Verleger, S.L. Nizhnaya, I.S. Bitensky, Atomic collisions on solid surfaces 93, 382 (North-Holland: Amsterdam: 1993).

14. J.F. Ziegler, J.P. Biersack, U. Littmark, The stopping and range of ions in solids, 321 (NY: Pergamon Press: 1985).

15. F.F. Umarov, A.A. Djurakhalov, K.M. Mukashev, NNC RK Bulletin 1, 10 (2018). 


\title{
Кутові розподіли розсіяних іонів Ne i Ar при ковзному падінні на поверхню InGaP (001) <110>
}

\author{
M.K. Karimov, U.O. Kutliev, K.U. Otabaeva, M.U. Otabaev
}

Urgench State University, 14, Khamid Olimjan St., Urgench 220100, Uzbekistan

\begin{abstract}
У роботі ми повідомляемо про вимірювання кутових розподілів при ковзному розсіянні іонів $\mathrm{Ne}$ та $\mathrm{Ar}$, що падають уздовж напрямку <110> поверхні InGaP (001). В наших розрахунках ми використовували метод наближення бінарних зіткнень. Специфіка теоретичного розгляду багаторазового розсіювання іонів атомами на поверхні твердого тіла, пов'язаного зі складністю опису взаемодії багатьох частинок, призвела до широкого використання методів моделювання процесу розсіювання на комп'ютері. Наші розрахунки показали, що зміни умов падіння бомбардуючих частинок призводять до зміни кутового розподілу. Це означае, що вивчення явища розсіювання іонів поверхнею зводиться до вивчення характерних траєкторій розсіяних іонів, що е кутовим розподілом. Ці характеристики досліджуються залежно від геометричних факторів (кути падіння та розсіювання, кристалографічні напрямки та тип кристалічної решітки), від типу частинок, що стикаються (іх маси), та початкової енергії $E_{0}$.
\end{abstract}

Ключові слова: Іон-тверді взаємодії, Розсіяння, Комп’ютерне моделювання. 